SDPS-2014

Printed in the United States of America, June, 2014

(C)2014 Society for Design and Process Science

\title{
CORPORATE DISCLOSURE AND COST OF EQUITY: CASE OF MALAYSIAN LISTED COMPANIES
}

\author{
${ }^{1}$ Mohd. Waliuddin Mohd. Razali, ${ }^{1}$ Rayenda Khresna Brahmana, and ${ }^{2}$ Ganisen \\ a/l Sinnasamy \\ ${ }^{1}$ Faculty of Economics and Business \\ Universiti Malaysia Sarawak \\ Kota Samarahan, Sarawak 94300, Malaysia \\ ${ }^{2}$ Faculty of Accounting \\ Universiti Teknologi Mara Melaka \\ Alor Gajah, Melaka, 7800, Malaysia
}

\begin{abstract}
Prior studies argue that information costs firm's capital due to the information asymmetry, and most of those research papers investigated develop countries. Malaysia, as an emerging market, offers its unique characteristic in terms of financial reporting regulation and is hugely influence by export-oriented firms. Therefore, this research aims to investigate whether information disclosure may affect the cost of equity of firms. We investigate this hypothesis by using all Malaysian listed firms excluding the finance, services, and utilities companies over 3 years period of 2010-2012. We use robust panel regression where the values are based on White robust standard errors that control for heterocedasticity errors. Overall, our findings are consistent with previous research that higher level of disclosure might discount the firm's cost of equity, suggesting that firms should disclose more information for better cost of capital. At the end of our research, we explain our findings using two perspectives which are: information cost and agency cost.
\end{abstract}

\section{INTRODUCTION}

With the sophistication in the business environment, information in corporate disclosure is becoming more important to business communities. The users of financial reports are more demanding and requesting better information of the company's performance. These users focus on the quality and timeliness of the relevant information in corporate disclosure for better decision making. The purpose is plain and simple: to attract cheaper external financing. Yosha (1995) found that firms may prefer bilateral to multilateral financing arrangements, in order to avoid disclosure which might leak to competitors. In the presence of a cost differential between these forms of financing, the higher quality firms (those with more to lose from disclosure) prefer bilateral financing. Francis (2005) concluded that firms with greater external financing needs have higher voluntary disclosure levels, and that an expanded disclosure policy for these firms leads to a lower cost of both debt and equity capital. Additionally, Hope et al (2011) found that firms with greater financial reporting credibility experience significantly lower perceived problems in gaining access to external finance. Further, the impact of financial credibility in reducing financing constraints in the presence of a controlling owner is more pronounced in countries with weaker creditor rights. In Malaysia context, large companies ponder the impacts of the disclosure to contingency liabilities and information asymmetry issue (Hashim and Salleh, 2007; Abdullah and Ismail, 2008), especially after the Asian financial crisis in 1997 (Ghazali and Weetman, 2006). Ho and Wong (2001, 2004) surmised that the extent of disclosure and transparency information has been highlighted to aid in turning the quality of investment and external financing decision, where corporate disclosures might reduce information asymmetries among firms and outside investors. This would lead companies to have cheaper financing.

The purpose of this study is to investigate the relationship between disclosure and cost of equity. Cost of equity is important for firms as it forms part of the total cost of capital and often considered in decision making process (Cotner and Fletcher, 2000) especially decision regarding investment. According to Beneda (2003), cost of equity is important because it forms a basis of comparison in evaluating investment opportunities. Therefore, it is imperative that firms maintain their cost of equity at a reasonable level because if it is too high, the firm has to loss its prospective investment. Meanwhile, disclosure shows the information of firms about items that is included in the financial statement through notes to financial statement (Shaw, 2003). Corporate disclosure emphasizes on financial data within the framework of generally accepted accounting principle.

The association between corporate disclosure and cost of equity is related to the information asymmetry. Botosan (1997) and Botosan and Plumlee (2002) found a 